\title{
Meningkatkan Penalaran Matematis Siswa pada Materi Ukuran Pemusatan Data melalui Pendekatan Problem Posing
}

\author{
Niila Amaalia Chasanah ${ }^{1}$, Sisworo ${ }^{1}$, Dwiyana ${ }^{1}$ \\ ${ }^{1}$ Pendidikan Matematika-Universitas Negeri Malang
}

\begin{tabular}{l}
\hline \hline INFO ARTIKEL \\
\hline Riwayat Artikel: \\
Diterima: 20-03-2019 \\
Disetujui: 24-04-2019 \\
\hline
\end{tabular}

Kata kunci:

reasoning;

problem posing;

centralized data size;

penalaran

problem posing;

ukuran pemusatan data;

\author{
Alamat Korespondensi: \\ Niila Amaalia Chasanah \\ Pendidikan Matematika \\ Universitas Negeri Malang \\ Jalan Semarang 5 Malang \\ E-mail: niilaamaaliac1988@gmail.com
}

\begin{abstract}
ABSTRAK
Abstract: This classroom action research aims to describe learning by using the problem posing approach that can improve students' mathemathical reasoning in central tendency material. There are 32 subjects from $12^{\text {th }}$ accounting grade students of SMK Wiyata Mandala Kepung. Problem posing learning that can improve mathematical reasoning in this study is learning with the following stages: observing problem, arranging questions and solving them, and present it. The results showed that $81,25 \%$ of students have minimum reasoning qualifications "Good".

Abstrak: Penelitian tindakan kelas ini bertujuan untuk mendeskripsikan pembelajaran dengan menggunakan pendekatan problem posing yang dapat meningkatkan penalaran matematis siswa pada materi ukuran pemusatan data. Subjek penelitian terdiri dari 32 siswa kelas 12 Akuntansi SMK Wiyata Mandala Kepung. Pembelajaran problem posing yang dapat meningkatkan penalaran matematis siswa pada penelitian ini memiliki tahapan mengamati permasalahan, menyusun pertanyaan dan menyelesaikannya, serta mempresentasikannya. Hasil penelitian menunjukkan bahwa $81,25 \%$ siswa memiliki kualifikasi penalaran minimal "Baik".
\end{abstract}

Prestasi matematika siswa di Indonesia saat ini cenderung masih tergolong dalam kategori rendah dibandingkan dengan negaranegara lain di dunia. Berdasarkan laporan hasil studi PISA pada tahun 2011 dan 2015 diketahui bahwa sebenarnya skor rata-rata matematika siswa Indonesia mengalami peningkatan. Skor rata-rata matematika siswa Indonesia pada tahun 2011 adalah 386 sementara pada tahun 2015 skor matematika siswa Indonesia adalah 397. Namun, peningkatan tersebut masih berada di bawah skor rata-rata TIMSS yaitu 500 (Mullis, Martin, Foy, \& Arora, 2015). Sumber informasi lain yang dapat menjadi parameter bahwa masih rendahnya prestasi matematika siswa Indonesia adalah laporan Pusat Penilaian Pendidikan terkait hasil Ujian Nasional tahun 2018. Berdasarkan laporan tersebut, diketahui bahwa rata-rata hasil ujian nasional mata pelajaran matematika yang diperoleh siswa tingkat Sekolah Menengah Pertama adalah 43,34. Sementara rata-rata hasil ujian nasional mata pelajaran Matematika siswa tingkat Sekolah Menengah Atas dan Kejuruan berada pada kisaran 32,72_36,46 (Puspendik, 2018). Rata-rata ini masih jauh dari target yang ditetapkan oleh Kementerian Pendidikan yaitu sebesar 55,00.

Kementerian Pendidikan menanggapi rendahnya hasil Ujian Nasional tahun 2018 pada mata pelajaran matematika sebagai akibat dari kurangnya penggunaan daya nalar siswa dalam menyelesaikan soal (Kemdikbud, 2018). Daya nalar atau penalaran secara umum diartikan sebagai suatu bentuk kegiatan untuk mengaitkan hubungan antara dua hal atau lebih dengan menggunakan dasar alasan tertentu dan menggunakan metode tertentu sehingga memperoleh suatu kesimpulan (Poespoprodja, \& Gilarso, 2006). Penalaran dalam matematika dapat diartikan sebagai penalaran yang berkaitan dengan matematika serta melibatkan objek-objek matematika (Brodie, 2010). Berdasarkan definisi tersebut, dapat ditarik suatu hubungan bahwa jika seorang siswa dikatakan belum mampu mengoptimalkan daya nalarnya dalam menyelesaikan soal matematika, maka salah satu penyebabnya adalah siswa tersebut belum mampu mengaitkan hubungan antara dua atau lebih informasi-informasi matematis yang tersedia pada soal sehingga memperoleh suatu kesimpulan.

Komponen kemampuan penalaran matematis, meliputi (a) analisis, (b) generalisasi,(c) sintesis, (d) justifikasi, dan (e) pemecahan masalah tidak rutin (Lindquist, Philpot, Mullis, \& Cotter, 2019). Berdasarkan urutan penarikan kesimpulan, Sumarmo, dkk (2017) merinci indikator kemampuan penalaran menjadi dua bagian, yaitu indikator penalaran induktif matematis dan deduktif. Indikator kemampuan penalaran induktif matematis, meliputi (a) menarik kesimpulan dari satu kasus ke kasus lainnya; (b) menarik kesimpulan berdasarkan keserupaan proses atau data; (c) menarik kesimpulan umum berdasarkan sejumlah data terbatas yang dicermati; (d) memperkirakan jawaban, solusi atau kecenderungan, interpolasi dan ekstrapolasi; (e) memberi 
penjelasan terhadap model, fakta, sifat, hubungan atau pola yang ada; (f) menggunakan pola hubungan untuk menganalisis situasi dan menyusun konjektur. Sementara itu, indikator penalaran deduktif, meliputi (a) melaksanakan perhitungan berdasarkan aturan atau rumus tertentu; (b) penalaran logis matematis yang terdiri dari penalaran proporsional, penalaran probabilistik, dan penalaran kombinatorial; (c) menyusun pembuktian langsung, tak langsung dan pembuktian induksi matematis. Berdasarkan beberapa indikator yang telah disampaikan di atas, maka pada penelitian ini indikator penalaran yang digunakan adalah: (1) melakukan perhitungan sesuai dengan aturan atau rumus ukuran pemusatan data; (2) menyusun kesimpulan yang logis berdasarkan alasanatau bukti yang sesuai; (3) menyusun analisis dari suatu permasalahan yang berhubungan dengan ukuran pemusatan data.

Materi matematika dan penalaran merupakan dua hal yang saling berkaitan. Materi matematika dipahami melalui kegiatan penalaran, sementara kemampuan penalaran dilatihkan menggunakan materi matematika. Sebagaimana telah diuraikan dalam NCTM, penalaran merupakan salah satu standar penting dalam belajar matematika (NCTM, 2000). Hal ini karena penalaran menjadi pondasi bagi standar proses yang lain (Safrida, As'ari, \& Sisworo, 2016). Siswa yang memiliki ketrampilan bernalar baik memiliki kesempatan lebih besar untuk berhasil dalam menyelesaikan masalah yang ditemui (Saleh, Prahmana, Isa, \& Murni, 2017; Ulya, Purwanto, Parta, \& Mulyati, 2017). Oleh karena itu, sangat penting untuk meningkatkan kemampuan penalaran siswa.

Ukuran pemusatan data merupakan salah satu materi yang terdapat dalam matematika. Beberapa penerapan materi ukuran pemusatan data berkaitan dengan proses pengambilan kesimpulan. Sebelum mengambil kesimpulan terhadap suatu data, seseorang perlu bernalar untuk memastikan apakah kesimpulan yang dibuat salah atau benar. Pada kenyataannya, pemanfaatan penalaran dalam ukuran pemusatan data bukan hanya pada disiplin ilmu matematika, tetapi juga dimanfaatkan oleh disiplin ilmu lainnya. Oleh karena itu, kemampuan penalaran siswa dalam materi ukuran pemusatan data penting untuk ditingkatkan.

Hasil penelitian pendahuluan terhadap 32 siswa kelas XII Akuntansi di SMK Wiyata Mandala pada masalah penerapan ukuran pemusatan data menunjukkan bahwa kualifikasi penalaran matematis siswa masih rendah. Persentase kualifikasi penalaran matematis siswa sebagai berikut: 9,375\% siswa memiliki kualifikasi penalaran sangat baik, 21,875\% berkualifikasi baik, 53,125\% siswa berkategori cukup baik dan 15,625\% berkategori kurang. Berdasarkan hasil analisis jawaban siswa pada tes pendahuluan diketahui bahwa rendahnya kualifikasi penalaran peserta didik akibat ketidakmampuan peserta didik mengaitkan informasi yang tersedia untuk menentukan penyelesaian dari permasalahan yang diberikan oleh guru.

Salah satu alternatif untuk meningkatkan penalaran adalah dengan melaksanakan pembelajaran problem posing (Wulandari, 2011). Melalui pembelajaran problem posing, terdapat tiga alternatif aktivitas kognitif yang dapat dilakukan siswa dalam pembelajaran. Ketiga aktivitas tersebut, meliputi pre-solution posing, within solution posing, dan post solution posing (Christou, Mousolides, Pittalis, Pitta-Pantazi, \& Sriraman, 2005). Menurut gejala yang ditunjukkan oleh siswa pada saat tes pendahuluan, maka peneliti memilih menerapkan within solution posing untuk memperbaiki alur bernalar siswa dalam menyelesaikan soal.

Berdasarkan uraian latar belakang di atas, peneliti menetapkan rumusan masalah dari penelitian ini adalah untuk mengetahui pembelajaran dengan pendekatan problem posing yang bagaimana yang dapat meningkatkan penalaran matematis siswa pada materi ukuran pemusatan data. Sedangkan tujuan penelitian ini adalah untuk mendeskripsikan pembelajaran dengan menggunakan pendekatan problem posing yang dapat meningkatkan penalaran matematis siswa pada materi ukuran pemusatan data.

\section{METODE}

Penelitian ini menggunakan pendekatan deskriptif kualitatif, yaitu peneliti mendeskripsikan hasil-hasil dan temuan selama penelitian. Sementara jenis penelitiannya adalah penelitian tindakan kelas dengan mengadopsi alur milik Kemmis \& Mc Taggart (2007). Rangkaian alur pada jenis penelitian ini membentuk suatu siklus yang dapat berulang apabila siklus sebelumnya belum memenuhi indikator keberhasilan. Masing-masing siklus memiliki alur (1) merencanakan, (2) melaksanakan dan mengamati, dan (3) merefleksi.

Penelitian dilakukan di SMK Wiyata Mandala Kepung pada semester ganjil tahun pelajaran 2018/2019. Subjek penelitian ini adalah siswa kelas 12 jurusan Akuntansi SMK Wiyata Mandala yang berjumlah 32 siswa. Subjek tersebut terbagi atas 3 siswa laki-laki dan 29 siswa perempuan. Dalam penelitian ini, peneliti memiliki peran ganda yaitu sebagai peneliti sekaligus sebagai guru matematika.

Perangkat pembelajaran yang digunakan pada penelitian ini, meliputi RPP dan LKPD, sedangkan instrumen penelitiannya menggunakan lembar validasi, lembar observasi, lembar tes akhir, dan angket pembelajaran. RPP disusun untuk setiap pertemuan dengan 2-3 indikator pencapaian kompetensi. LKPD berisi sebuah permasalahan yang harus diselesaikan oleh siswa menggunakan langkah-langkah pembelajaran problem posing. Lembar validasi dan lembar observasi berisi petunjuk pengisian skor, uraian indikator yang akan dinilai, dan kolom pensekoran. Lembar tes akhir berisi soal uraian yang disesuaikan dengan indikator penalaran yang telah ditetapkan, sedangkan angket pembelajaran berisi daftar pertanyaan daring yang menggambarkan respons siswa terhadap pembelajaran problem posing dan tingkat kepercayaan diri siswa dalam menyelesaikan soal materi ukuran pemusatan data.

Prosedur penelitian ini adalah (1) tahap perencanaan, dalam tahap ini peneliti melakukan identifikasi terhadap permasalahan awal yang ada di kelas. Selanjutnya peneliti menyusun perangkat pembelajaran dan instrumen penelitian kemudian meminta validator untuk melakukan validasi perangkat dan instrumen penelitian. (2) tahap pelaksanaan, dalam tahap ini peneliti melaksanakan langkah-langkah pembelajaran sebagaimana tertuang dalam RPP dan meminta siswa untuk menyelesaikan 
permasalahan yang tersedia di LKPD. (3) tahap pengamatan, pada tahap ini peneliti meminta bantuan dua orang guru sebagai observer yang bertugas untuk mengamati tindakan yang dilakukan guru dan tindakan yang dilakukan siswa selama pembelajaran. (4) tahap refleksi, dalam tahap ini peneliti melihat kembali catatan kejadian yang terjadi selama pembelajaran, hasil angket pembelajaran dan saran yang diberikan oleh observer. Hasil dari refleksi ini digunakan untuk memperbaiki tindakan pada siklus selanjutnya.

Data kualitatif pada penelitian ini berupa hasil wawancara selama pembelajaran, foto jawaban siswa dan angket pembelajaran di akhir siklus. Data tersebut selanjutnya dianalisis menggunakan tahapan (1) penyederhanaan data, (2) penyajian data, dan (3) penarikan kesimpulan (Miles, Huberman, \& Saldana, 2014). Data kuantitatif pada penelitian ini diperoleh dari skor hasil validasi, skor hasil pengamatan, dan skor hasil tes siswa. Data tersebut dihitung skor rata-ratanya berdasarkan rumus yang telah ditentukan sebelumnya oleh peneliti kemudian disimpulkan kategori datanya. PTK ini dikatakan berhasil apabila memenuhi dua kriteria berikut, (a) skor rata-rata hasil pengamatan kegiatan guru dan siswa berada pada kriteria baik, dan (b) paling sedikit $75 \%$ dari siswa yang mengikuti tes akhir memiliki rata-rata skor kemampuan penalaran matematis berkualifikasi minimal baik.

\section{HASIL}

Tahap pertama adalah perencanaan, pada tahap ini peneliti menyusun perangkat pembelajaran meliputi RPP dan LKPD serta menyusun instrumen penelitian yang meliputi lembar observasi kegiatan guru, lembar observasi kegiatan siswa, lembar tes akhir, angket pembelajaran dan lembar validasi. Seluruh perangkat pembelajaran dan instrumen yang telah disusun selanjutnya divalidasi oleh seorang dosen dari Pendidikan Matematika Universitas Negeri Malang dan seorang guru Matematika SMK Wiyata Mandala Kepung. Dari proses validasi tersebut diperoleh hasil bahwa seluruh perangkat dan instrumen dinyatakan valid dengan beberapa revisi.

Tahap kedua adalah pelaksanaan dan pengamatan pelaksanaan pembelajaran. Pada tahap ini siswa dibagi menjadi beberapa kelompok. Pelaksanaan pembelajaran masing-masing pertemuan pada penelitian ini terbagi menjadi tiga bagian, yaitu pendahuluan, inti, dan penutup. Pada bagian pendahuluan, guru mempersiapkan siswa untuk mengikuti pembelajaran. Selanjutnya, guru memulai apersepsi dengan melakukan tanya jawab terhadap siswa terkait materi ukuran pemusatan data yang pernah diterima pada jenjang pendidikan sebelumnya. Setelah dirasa cukup guru mengajak siswa untuk memulai pembelajaran. Pembelajaran problem posing pada penelitian ini dilaksanakan dengan tahapan (1) mengamati permasalahan, (2) menyusun pertanyaan, (3) menerapkan strategi penyelesaian soal, dan (4) mempresentasikan jawaban. Penjelasan selengkapnya sebagai berikut.

Pertama, tahap mengamati permasalahan. Pada tatap muka pertama siklus pertama, tahap ini digunakan peneliti untuk memperkenalkan metode pengajuan pertanyaan within solution posing. Kemudian, pada tatap muka selanjutnya siswa disajikan permasalahan di LKPD dengan metode post solution posing dan within solution posing. Kedua, tahap menyusun pertanyaan. Pada tatap muka pertama siklus pertama, tahap ini digunakan peneliti untuk melatih siswa menyusun pertanyaan within solution posing. Pertanyaan tipe within solution posing digunakan untuk membantu mencari informasi yang belum tersedia pada soal dan dibutuhkan untuk menentukan penyelesaian. Ketiga, tahap menerapkan strategi penyelesaian. Pada tahap ini siswa dipersilahkan untuk menjawab pertanyaan-pertanyaan tipe witin solution posing yang telah disusun pada tahap sebelumnya. Pada tahap ini siswa juga dipersilahkan untuk mempertukarkan soal tipe post solution posing dengan kelompok lain dan menyelesaikannya. Keempat, tahap mempresentasikan jawaban. Pada tahap ini guru memilih secara acak perwakilan kelompok untuk mempresentasikan hasil kerja kelompok di depan kelas. Kelompok lain diminta untuk memberi tanggapan atas presentasi yang disajikan.

Pada kegiatan penutup, peneliti mengajak siswa untuk mereview kembali pembelajaran yang telah dilakukan. Peneliti melakukan tanya jawab terkait apa yang telah dipelajari pada masing-masing pertemuan. Selanjutnya, guru memberikan latihan atau penugasan individu untuk dikerjakan siswa di rumah. Tugas yang diberikan berisi soal tentang materi yang telah diajarkan pada pertemuan sebelumnya dan soal latihan untuk materi pertemuan berikutnya.

Hasil pelaksanaan pembelajaran pada siklus pertama dan kedua diperoleh beberapa catatan pembelajaran sebagai berikut: (1) guru telah melaksanakan langkah-langkah pembelajaran problem posing sesuai dengan rencana pelaksanaan pembelajaran yaitu mengamati, mengajukan pertanyaan, menerapkan strategi untuk menyelesaikan soal, dan mempresentasikan jawaban, (2) pada tatap muka ke-1, hanya peserta didik dengan kemampuan tinggi yang terlihat aktif dalam menyelesaikan soal di LKPD sementara anggota yang lain hanya memperhatikan penyelesaian soal tersebut, (3) pada siklus pertama tatap muka ke-2 peneliti menerapkan aturan untuk memberikan bonus bagi kelompok yang aktif dan hukuman bagi kelompok yang kurang aktif. Aturan ini cukup memberikan perubahan bagi keaktifan anggota dalam kelompok, (4) melebihi ketentuan, (5) hanya siswa yang memiliki penalaran sangat baik yang mampu menyusun soal post solution posing dan menyelesaikannya, (6) beberapa tujuan pembelajaran pada siklus pertama tidak tercapai dalam satu pertemuan, (7) pembelajaran siklus kedua tatap muka ketiga dilakukan secara individu (tidak dalam kelompok). Siswa berlatih secara mandiri untuk menyelesaikan soal-soal ukuran pemusatan data dengan menerapkan within solution posing, dan (8) lebih banyak siswa yang tampak percaya diri dalam menyelesaikan soal-soal latihan pada siklus kedua pertemuan ketiga

Hasil pengamatan terhadap pelaksanaan pembelajaran terbagi menjadi dua unsur, yaitu hasil pengamatan kegiatan guru dan hasil kegiatan siswa. Skor dari hasil pengamatan tersebut selanjutnya dikategorikan menjadi "Baik", "Cukup Baik", dan "Kurang". Hasil pengamatan kegiatan guru pada siklus pertama tatap muka 1 diperoleh rata-rata skor 3,6 dan tatap muka 2 diperoleh rata-rata skor 3,6. Hasil pengamatan kegiatan siswa pada siklus pertama tatap muka 1 diperoleh skor rata-rata 3,2 dan 
tatap muka 2 diperoleh rata-rata skor 3,4. Selanjutnya, hasil pengamatan kegiatan guru pada siklus kedua tatap muka 1, 2, dan 3 diperoleh rata-rata skor 3,8. Sedangkan hasil pengamatan kegiatan siswa pada siklus kedua tatap muka 1 diperoleh rata-rata skor 3,6 dan hasil pengamatan tatap muka 2 dan 3 diperoleh kategori rata-rata skor 3,8.

Tahap ketiga adalah refleksi, pada tahap ini guru melakukan refleksi untuk memperbaiki pembelajaran pada pertemuan selanjutnya. Data yang digunakan sebagai pertimbangan dalam refleksi pembelajaran pada penelitian ini adalah data hasil tes akhir, catatan pelaksanaan pembelajaran dan hasil angket pembelajaran siklus pertama. Berikut adalah tabel hasil tes akhir beserta kualifikasinya.

Tabel I. Hasil Tes Akhir Siklus Pertama dan Kedua

\begin{tabular}{ccccc}
\hline \multirow{2}{*}{ No } & \multirow{2}{*}{ Rentang skor } & \multicolumn{2}{c}{ Banyaknya Peserta Didik } & \multirow{2}{*}{ Kualifikasi Tingkat Penalaran } \\
\cline { 3 - 4 } & & Siklus Pertama & Siklus Kedua & \\
\hline 1. & $75 \leq x \leq 100$ & 9 & 12 & Sangat Baik \\
\hline 2. & $50 \leq x<75$ & 9 & 14 & Baik \\
\hline 3. & $25 \leq x<50$ & 14 & 6 & Cukup Baik \\
\hline 4. & $0 \leq x<25$ & 0 & 0 & Kurang \\
\hline
\end{tabular}

Hasil angket pembelajaran siklus pertama diperoleh informasi bahwa: (1) sebanyak 87,1\% siswa merasa belajar dengan cara diskusi kelompok sangat menyenangkan dan 12,9\% siswa merasa biasa saja; (2) sebanyak 78,125 siswa menyatakan bahwa metode within solution posing sangat membantu mereka dalam menyelesaikan soal dan $21,875 \%$ siswa menyatakan masih bingung dengan metode within solution posing; (3) sebanyak 71,875\% siswa mengaku kadang-kadang masih menemui kesulitan dalam mengajukan soal, 18,75\% siswa mengaku tidak mengalami kesulitan dan 9,375\% menyampaikan selalu kesulitan; (4) sebanyak 59,375\% peserta didik memiliki kepercayaan tinggi telah menguasai materi mean, median dan modus data tunggal. Sejumlah $21,875 \%$ peserta didik memiliki kepercayaan diri yang tinggi bahwa telah menguasai materi median dan modus data tunggal. Dan sisanya menyatakan sangat percaya diri menguasai materi median data tunggal saja atau modus data tunggal saja, (5) Sebanyak 60\% siswa memberikan saran untuk diajari kembali cara membuat pertanyaan within solution posing.

Hasil angket pembelajaran siklus kedua diperoleh informasi bahwa (1) sebanyak 100\% siswa merasa belajar dengan cara diskusi kelompok sangat menyenangkan; (2) sebanyak $81,25 \%$ siswa menyatakan bahwa metode within solution posing sangat membantu mereka dalam menyelesaikan soal dan $18,75 \%$ siswa menyatakan masih bingung dengan metode within solution posing; (3) sebanyak 56,25\% siswa mengaku kadang-kadang masih menemui kesulitan dalam mengajukan soal, 43,75\% siswa mengaku tidak mengalami kesulitan; (4) sebanyak 81,25\% peserta didik memiliki kepercayaan tinggi telah menguasai materi mean, median dan modus data kelompok. Sejumlah $75 \%$ peserta didik memiliki kepercayaan diri yang tinggi bahwa telah menguasai materi median dan modus data kelompok, sisanya menyatakan sangat percaya diri menguasai materi median data kelompok saja atau modus data kelompok saja.

Berdasarkan hasil observasi, hasil tes siklus, hasil angket pembelajaran dan catatan hasil pelaksanaan pembelajaran, maka peneliti melakukan refleksi siklus pertama sebagai berikut. Pertama, pembelajaran yang dilakukan pada siklus pertama telah mencerminkan pendekatan problem posing sehingga pada siklus selanjutnya harus dipertahankan. Kedua, skor rata-rata hasil observasi kegiatan guru dan kegiatan siswa berada pada kategori Baik. Ketiga, tujuan pembelajaran yang ingin dicapai dalam satu pertemuan terlalu banyak sehingga pembelajaran yang dilakukan dalam waktu 2x45 menit kurang efektif. Pada siklus selanjutnya akan ditetapkan tujuan pembelajaran yang lebih memungkinkan untuk dicapai dalam satu pertemuan. Keempat, pemberian bonus nilai bagi peserta didik yang aktif dan hukuman bagi kelompok yang anggotanya pasif cukup memberikan perubahan pada keaktifan peserta didik. Metode ini akan tetap digunakan pada siklus selanjutnya. Kelima, metode post solution posing hanya dapat dikerjakan oleh peserta didik yang memiliki kemampuan penalaran sangat baik. Hal tersebut kurang memberikan efek peningkatan penalaran pada siswa dengan kualifikasi penalaran dibawahnya. Oleh karena itu, pada siklus selanjutnya peneliti akan fokus pada satu metode yaitu membelajarkan metode within solution posing untuk meningkatkan penalaran peserta didik dalam menyelesaikan soal. Keenam, sebanyak 56,25\% siswa yang mengikuti tes akhir memiliki kualifikasi penalaran minimal Baik. Perlu adanya perubahan strategi untuk meningkatkan persentase banyaknya siswa yang memiliki kualifikasi minimal Baik.

Refleksi siklus kedua, meliputi (1) pembelajaran yang dilakukan pada siklus kedua telah mencerminkan pendekatan problem posing yang bersesuaian dengan RPP, (2) fase menyusun pertanyaan dan fase menerapkan strategi penyelesaian soal yang dijadikan satu fase pada siklus kedua membuat siswa lebih mudah menyusun pertanyaan, (3) skor rata-rata hasil observasi kegiatan guru dan kegiatan siswa berada pada kategori Baik, (4) lebih banyak siswa yang merasa percaya diri dalam menyelesaikan soal dengan bantuan within solution posing, (5) latihan soal secara individu sebelum pelaksanaan tes membantu siswa melatih kelancaran siswa dalam menyusun soal tipe within solution posing, dan (6) sebanyak $81,25 \%$ siswa yang mengikuti tes akhir memiliki kualifikasi penalaran minimal Baik. 


\section{PEMBAHASAN}

Pada bagian ini akan dibahas karakteristik pembelajaran problem posing yang dapat meningkatkan penalaran siswa kelas 12 Akuntansi SMK Wiyata Mandala Kepung, hasil pengamatan dan hasil tes akhir. Berikut uraian karakteristik pembelajaran problem posing yang dapat meningkatkan penalaran siswa kelas 12 Akuntansi SMK Wiyata Mandala Kepung. Pertama, kegiatan mengamati permasalahan. Pada awalnya guru memberikan tayangan permasalahan penerapan ukuran pemusatan data dalam konteks nyata. Penyelesaian dari permasalahan yang ditayangkan tersebut hanya melibatkan kemampuan prosedural. Hal ini dilakukan untuk mengecek kemampuan siswa dalam melakukan perhitungan sesuai dengan aturan atau rumus ukuran pemusatan data. Selanjutnya guru menyusun soal post solution posing dari permasalahan yang telah diselesaikan menggunakan cara prosedural tadi. Soal post solution posing yang dibuat digunakan guru untuk memberikan contoh kepada siswa cara mengajukan pertanyaan bantuan atau within solution posing. Selanjutnya guru membentuk delapan kelompok dengan anggota $1-4$ siswa. Model pembelajaran problem posing akan lebih efektif dilakukan di dalam kelas secara berkelompok (Setiawan, 2015). Siswa dengan kemampuan tinggi diharapkan dapat membantu teman dalam kelompoknya yang memiliki tingkat kemampuan lebih rendah.

Kedua, kegiatan menyusun pertanyaan dan menerapkan strategi penyelesaian. Berdasarkan hasil pelaksanaan siklus pertama dan kedua, siswa kelas 12 Akuntansi SMK Wiyata Mandala merasa lebih mudah dalam menyusun pertanyaan within solution posing jika menggunakan strategi kerja mundur. Maksudnya siswa menuliskan terlebih dahulu pertanyaan tentang rumus yang akan digunakan kemudian menuliskan jawaban dari pertanyaan tersebut. Selanjutnya, secara bertahap menerapkan strategi kerja mundur untuk menentukan informasi-informasi yang dibutuhkan dalam menyelesaikan soal. Penerapan strategi kerja mundur ini merupakan salah satu cara yang dianggap efektif diterapkan bagi siswa dalam beragam kemampuan untuk menyelesaikan soal yang tidak prosedural (Fauziah \& Setiawan, 2018; Muayanah, 2017). Pada saat siswa melakukan diskusi dengan kelompok untuk menyusun pertanyaan dan menerapkan strategi penyelesaian, guru berkeliling untuk memantau diskusi dan memberikan bimbingan bila diperlukan. Bimbingan ini dapat membantu memahamkan siswa terhadap materi maupun prosedur yang diajarkan (Moalosi, 2013).

Ketiga, kegiatan mempresentasikan jawaban. Pada tahap ini, guru meminta salah satu perwakilan kelompok untuk melakukan presentasi di depan kelas. Kemudian kelompok lain menanggapi hasil presentasi. Kegiatan presentasi ini sangat bermanfaat untuk melatih kepercayaan diri siswa berbicara di depan umum. Selain itu melalui kegiatan presentasi siswa memiliki kesempatan untuk mengomunikasikan idenya kepada orang lain. Selanjutnya, guru memberi penguatan atas jawaban benar siswa dan meluruskan pendapat siswa yang belum tepat.

Hasil observasi atau pengamatan terhadap kegiatan guru dan siswa diperoleh bahwa observasi kegiatan guru siklus pertama menunjukkan kategori "Baik". Hasil pengamatan terhadap kegiatan siswa pada siklus pertama juga menunjukkan kriteria "Baik". Selanjutnya hasil pengamatan kegiatan guru pada siklus kedua menunjukkan kategori "Baik" dan hasil pengamatan terhadap kegiatan siswa pada siklus kedua juga berkategori "Baik". Terdapat kenaikan rata-rata skor hasil pengamatan kegiatan guru dari 3,6 ke 3,8.Sementara untuk rata-rata skor pengamatan kegiatan siswa juga mengalami kenaikan dari 3,2 di awal pertemuan menjadi 3.8 di pertemuan terakhir.

Hasil tes akhir siklus terbagi dalam dua bagian, yaitu hasil tes siklus pertama dan hasil tes siklus kedua. Pada tes siklus pertama, terdapat tiga soal yang dikerjakan oleh siswa. Diketahui soal nomor 1 adalah soal yang berkaitan dengan mean data tunggal dengan indikator melakukan perhitungan sesuai dengan aturan ukuran pemusatan data. Soal nomor 2 adalah soal yang berkaitan dengan median data tunggal dengan indikator menyusun kesimpulan berdasarkan alasan yang benar. Soal no. 3 adalah soal yang berkaitan dengan modus dengan indikator melakukan analisis terhadap permasalahan yang berkaitan dengan ukuran pemusatan data. Dari ketiga soal yang dikerjakan oleh siswa pada tes siklus pertama, diketahui bahwa banyaknya siswa yang memiliki skor akhir berkategori minimal "Baik" sebesar 56,25\%. Hasil ini masih di bawah indikator keberhasilan. Dengan kata lain pembelajaran pada siklus pertama belum berhasil. Selanjutnya pada siklus kedua, siswa mengerjakan soal tes akhir yang terdiri dari 2 soal. Soal pertama berkaitan dengan mean data kelompok dengan indikator menyusun kesimpulan berdasarkan alasan yang benar. Selanjutnya soal kedua berkaitan dengan median dan modus data kelompok dengan indikator melakukan analisis terhadap permasalahan yang berkaitan dengan ukuran pemusatan data. Berdasarkan skor yang diperoleh siswa pada tes siklus kedua, diperoleh bahwa banyaknya siswa yang memperoleh skor kategori minimal "Baik" adalah sebesar 81,25 \%. Persentase ini telah memenuhi indikator keberhasilan.

\section{SIMPULAN}

Berdasarkan uraian yang telah disampaikan di atas, dapat diperoleh beberapa kesimpulan bahwa pembelajaran problem posing dapat meningkatkan penalaran matematis siswa kelas 12 Akuntansi SMK Wiyata Mandala pada materi ukuran pemusatan data adalah pembelajaran yang menerapkan langkah-langkah sebagai berikut.

Pertama, mengamati permasalahan, tahap ini terdiri dari kegiatan pemberian apersepsi materi, kegiatan pemberian contoh cara menyusun pertanyaan within solution posing, pemberian contoh cara menyusun soal post solution posing dan penyajian masalah yang akan diselesaikan oleh siswa. 
Kedua, menyusun pertanyaan dan menerapkan strategi penyelesaian. Pada tahap ini strategi yang paling membantu terutama bagi siswa yang memiliki kemampuan matematika sedang dan rendah adalah strategi kerja mundur. Berdasar dari informasi yang diketahui siswa, secara bertahap siswa menyusun pertanyaan dari informasi yang belum diketahui kemudian menuliskan cara menjawabnya, dan apabila terdapat informasi yang belum diketahui, siswa menyusun pertanyaan kembali dan menjawabnya. Hasil jawaban tersebut digunakan untuk menjawab pertanyaan sebelumnya.

Ketiga, mempresentasikan jawaban. Tahap ini berfungsi untuk menumbuhkan percaya diri siswa dalam menyampaikan idenya. Tahap ini juga dapat digunakan oleh guru melihat bagaimana siswa yang melakukan presentasi bernalar dalam menyelesaikan soal. Pembelajaran problem posing dengan langkah-langkah di atas telah dapat meningkatkan penalaran siswa pada materi ukuran pemusatan data. Informasi ini dapat terlihat dari hasil tes akhir. Diketahui hasil tes siklus pertama sebanyak $56,25 \%$ siswa memiliki kategori penalaran matematis minimal "Baik". Kemudian meningkat pada siklus kedua, yaitu sebanyak 81,25\% siswa memiliki kualifikasi penalaran minimal "Baik". Dapat disimpulkan bahwa penelitian telah memenuhi kriteria keberhasilan.

Berdasarkan hasil penelitian yang telah dilakukan terdapat beberapa saran yang dapat diberikan. Saran bagi guru yang akan melaksanakan pembelajaran problem posing pertama kali di sekolahnya sebaiknya memperhatikan alokasi waktu dan sebaran kemampuan peserta didik. Karena untuk mengajukan pertanyaan, butuh pembiasaan dan kemampuan yang cukup baik dari siswa. Jika banyaknya siswa yang memiliki kemampuan matematis tinggi sangat sedikit di kelas maka pembelajaran problem posing perlu dimodifikasi dengan metode yang lain.

\section{DAFTAR RUJUKAN}

Brodie, K. (2010). Teaching Mathematical Reasoning in Secondary School Classroom. New York: Springer. Christou, C, Mousolides, N, Pittalis, M, Pitta-Pantazi, D, \& Sriraman, B. (2005). An Empirical Taxonomy of Problem Posing Processes, 37(3), 149-158.

Fauziah, A. N., \& Setiawan, R. (2018). Analisis Strategi Bekerja Mundur dan Ekuivalensi pada Permasalahan Non Rutin Sistem Persamaan. Jurnal Pendidikan Matematika dan Matematika, 2(1), 79-88.

Lindquist, M., Philpot, R., Mullis, I. V.S., \& Cotter, K.E. (2019). Mathematics Cognitive Domains-Fourth and Eight Grades (TIMSS 2019 Mathematics Framework). Chestnut Hill, MA: TIMSS \& PIRLS International Study Center, Boston College.

Miles, M.B., Huberman, A.M., \& Saldana, J. (2014). Qualitative Data Analysis, A Methods Sourcebook (3 ed.). USA: Sage Publication.

Moalosi, W. T. S. (2013). Effects of Direct Instruction and Social Constructivism on Learners' Congnitive Development: A Comparative Study. Academic Research International, 4(6), 301-305.

Muayanah, M. (2017). Penerapan Strategi Pemecahan Masalah 'Bekerja Mundur' (Work Backward) untuk Meningkatkan Keterampilan Menyelesaikan Soal Cerita Matematika Materi Pecahan pada Siswa Kelas IV SDN Watesnegoro 3 Kecamatan Ngoro Kabupaten Mojokerto. Prosiding TEP \& PDs, 4(31), 389-395.

Mullis, I. V.S., Martin, M.O, Foy, P, \& Arora, A. (2015). TIMSS 2015 International Results in Mathematics (International Student Achievement in The TIMSS Mathematics Content and Cognitive Domains.). Chestnut Hill, MA: TIMSS \& PIRLS International Study Center, Boston College.

NCTM. (2000). Principles and Standards for School Mathematics. Reston, VA: NCTM.

Poespoprodja, W, \& Gilarso, E.T. (2006). Logika Ilmu Menalar: Dasar-Dasar Berpikir Tertib, Logis, Kritis, Analitis, Dialektis. Bandung: Pustaka Grafika.

Puspendik. (2018). Laporan Hasil Ujian Nasional Tahun Pelajaran 2017/2018. Jakarta: Kementerian Pendidikan dan Kebudayaan. (online) (https://puspendik.kemdikbud.go.id/hasil-un/, diakses 10 Oktober 2018)

Safrida, L. N., As'ari, A. R., \& Sisworo. (2016). Pengembangan Perangkat Pembelajaran Berbasis Problem Solving Polya Untuk Meningkatkan Kemampuan Penalaran Matematis Siswa Materi Peluang Kelas XI SMA. Jurnal Pendidikan: Teori, Penelitian, dan Pengembangan, 1(4), 583-591.

Saleh, M., Prahmana, R. C. I., Isa, M., \& Murni, M. (2017). Improving the Reasoning Ability of Elementary School Student through the Indonesian Realistic Mathematics Education. Journal on Mathematics Education, 9(1). https://doi.org/10.22342/jme.9.1.5049.41-54

Setiawan, R. (2015). Penerapan Pembelajaran dengan Pendekatan Problem Posing untuk Meningkatkan Pemahaman Peluang Siswa Kelas X SMK Negeri 5 Malang. Tesis tidak diterbitkan. Universitas Negeri Malang, Malang.

Ulya, W. T., Purwanto, P., Parta, I. N., \& Mulyati, S. (2017). "ELIP-MARC” Activities via TPS of Cooperative Learning to Improve Student's Mathematical Reasoning. International Education Studies, 10(10), 50. https://doi.org/10.5539/ies.v10n10p50

Wulandari, E. (2011). Meningkatkan Kemampuan Penalaran Matematis Siswa melalui Pendekatan Problem Posing di Kelas VIII A SMP Negeri 2 Yogyakarta. Tesis tidak diterbitkan. Universitas Negeri Yogyakarta, Yogyakarta. 